\title{
Physiological response to irradiance, temperature and co-cultivation in Antarctic engineering brown algae (Desmarestia menziesii and $D$. anceps)
}

\author{
Valentina Savaglia ${ }^{1,4}\left(\mathbb{D} \cdot\right.$ Carolina Veronica Matula ${ }^{2} \cdot$ Maria Liliana Quartino $^{2}$. Mariano Valli Francione . $^{3}$ \\ Katharina Zacher ${ }^{4}$
}

Received: 8 January 2019 / Revised: 19 July 2019 / Accepted: 3 September 2019

(c) Springer-Verlag GmbH Germany, part of Springer Nature 2019

\begin{abstract}
The Western Antarctic Peninsula (WAP) is a hot spot of global warming, including decreased sea-ice cover during winter and increased sedimentation during summer due to glacial melt. Subsequently, an altered irradiance and temperature regime in the water column may affect the performance of primary producers and change competitive structures. The brown, subtidal macroalgae Desmarestia menziesii and D. anceps are ecosystem engineers and of extreme importance for the Antarctic coastal ecosystem. Individuals of both species were collected from the field during the austral summer and exposed in two experiments to different temperatures $\left(2\right.$ and $7{ }^{\circ} \mathrm{C}$ ) or different irradiances (high and low) in combination with co-culturing the two algal species together (two-factorial design). No temperature, irradiance or co-cultivation effects on growth rates of $D$. menziesii and $D$. anceps were detected, but effects were possibly masked by the very low growth rates. Both $D$. menziesii and $D$. anceps are season anticipators, showing highest growth in late winter/spring and a dormancy state during summer. Photosynthetic efficiency was usually higher at $2{ }^{\circ} \mathrm{C}$ and low irradiance conditions compared to $7{ }^{\circ} \mathrm{C}$ and high irradiance and no co-culturing effects were detected. Parameters derived from P-E curves $\left(\mathrm{rETR}_{\max }, E_{\mathrm{k}}\right.$ and $\left.\alpha\right)$ were higher in D. menziesii compared to $D$. anceps, reflecting zonation patterns in the field. Future multifactorial experiments, taking seasons and different life-stages into account, are particularly needed to elucidate year-round effects of global warming on macroalgal key species that form the energetic base of the Antarctic coastal food webs.
\end{abstract}

Keywords Coastal ecosystems · Global climate change · Phaeophyceae · Photosynthesis · Growth · Polar macroalgae · Season anticipators

Electronic supplementary material The online version of this article (https://doi.org/10.1007/s00300-019-02578-1) contains supplementary material, which is available to authorised users.

Valentina Savaglia

Valentina.Savaglia@uliege.be

Katharina Zacher

Katharina.Zacher@awi.de

1 Centre for Protein Engineer, Université de Liège, Allée du Six Août 13, Quartier Agora, Sart-Tilman, 4000 Liège, Belgium

2 Instituto Antártico Argentino, 25 de Mayo 1143, San Martín, B1650 Buenos Aires, Argentina

3 National University of Luján, Avenida Constitución, Ruta 5, B6702 Buenos Aires, Argentina

4 Alfred Wegener Institute Helmholtz Centre for Polar and Marine Research, Am Handelshafen 12, 27570 Bremerhaven, Germany

\section{Introduction}

The Western Antarctic Peninsula (WAP) has been described as an area highly vulnerable to the effects of climate change (Clarke et al. 2006; Ducklow et al. 2013; Turley 2013; IPCC 2018). This region is experiencing one of the fastest warming rates in the world (Turner et al. 2009), with a rise in atmospheric temperature of nearly $3{ }^{\circ} \mathrm{C}$ since 1951 (Meredith and King 2005), although slowing down in recent years (Turner et al. 2016). At Potter Cove (King George Island/ Isla 25 de Mayo, WAP) average water temperatures increased by $0.32{ }^{\circ} \mathrm{C}$ per decade and winter sea surface temperature by more than $2{ }^{\circ} \mathrm{C}$ between 1991 and 2006 (Schloss et al. 2012). This increase in water temperature may have profound consequences for shallow polar marine ecosystems, which consist of strongly cold-water-adapted organisms (Clark et al. 2013). Furthermore, high-latitude areas 
suffer from sea-ice loss and retreating glaciers (Cook et al. 2005; Quartino et al. 2013), leading to an increased sediment inflow during the melting season (spring to summer). The consequent reduced light penetration into the water column may affect primary producers along the coastline (Quartino et al. 2013; Deregibus et al. 2016).

Seaweeds are very important primary producers in polar coastal ecosystems, building highly complex underwater forests in the sublittoral rocky shores of the WAP (Wiencke et al. 2014). These seaweed communities play a key role in the Antarctic coastal system, similar to Laminariales (kelp) communities that colonise temperate to Polar rocky coasts of the Atlantic and Pacific Ocean (Clayton 1994). Due to the very low phytoplankton biomass and productivity in some Antarctic shallow coasts, such as Potter Cove—our study area (Hapter et al. 1983; Schloss et al. 1997, 1998, 2002a), seaweeds may be a much more important-year round—carbon source for the Antarctic benthos than in temperate seas (Reichardt 1987). At Potter Cove seaweeds were identified as the main energy source for all consumers and detritivores, forming the energetic base of Potter Cove food web (Marina et al. 2018; Cordone et al. 2018). The order Desmarestiales (Phaeophyceae) represents the dominant taxonomic group within the seaweed community, whose canopy can reach up to $80 \%$ of the total macroalgal biomass (Amsler et al. 1995; Quartino and Boraso de Zaixso 2008). Species of this order provide a three-dimensional habitat and a physical shelter for a large number of invertebrates, such as amphipods, epi- and endophytes, and other associated organisms (Amsler et al. 1995; Carlsen et al. 2007; Huang et al. 2007; Bartsch et al. 2008; Barrera-Oro et al. 2018). The perennial Antarctic endemic Desmarestia menziesii J. Agardh and Desmarestia anceps Montagne form the highest macroalgal biomass in Antarctic coastal areas (together with Himantothallus grandifolius; Amsler et al. 1995; Brouwer 1996). Quartino and Boraso de Zaixso (2008) and Gómez et al. (2009) showed that they may reach maxima of up to $10 \mathrm{~kg}$ fresh weight $\mathrm{m}^{-2}$ at some sites. Desmarestia menziesii is a circum-Antarctic species occurring between the Ross Seas and South Georgia Islands, whereas growth of $D$. anceps is mainly restricted to areas around the WAP (Wiencke et al. 2014). Generally, the zonation pattern of the large brown algae is relatively consistent over various sites in Antarctica. While D. menziesii dominates the shallow sublittoral zone between 3 and $5 \mathrm{~m}, D$. anceps is dominant around $10 \mathrm{~m}$ water depths. Both species may co-occur at all depths (Quartino et al. 2001; Wiencke et al. 2014), however, at some sites, only one of these species is present (Wiencke et al. 2014). The vertical depth and biogeographical distribution of macroalgae is mainly controlled by the individual irradiance and temperature requirements of each species (Bartsch et al. 2008; Karsten et al. 2009; Bartsch et al. 2012). Species develop morpho-functional traits that allow them to cope with a determinate depth and latitude (Gómez et al. 2019). Therefore, it is likely that global change will impact the distribution, performance and survival of seaweeds as it alters both temperature regime and irradiance in the water column. Other abiotic factors influencing macroalgal vertical distribution include wave exposure, substrate type and bottom topography (Klöser et al. 1996) as well as other still unknown factors which may shape the local algal distributions (Wiencke et al. 2014).

Besides the regulatory role of abiotic factors, interspecific competition is often considered the major selective force in algal communities determining diversity, species distribution and the biomass and structure of algal communities (Nabivailo and Titlyanov 2006; Barner et al. 2016; Traiger and Konar 2017). Few studies have investigated interspecific relationships among benthic seaweeds occupying the same niche (Reed 1990; Xu et al. 2013; Nabivailo et al. 2014; Chen et al. 2015; Barner et al. 2016), particularly at high latitudes (but see Zacher et al. 2016). Little information is available on the interplay between abiotic and biotic conditions, which is fundamental in order to understand the succession of seaweed communities (Nabivailo et al. 2014; Barner et al. 2016). Interspecific competition may result from "resource" and "interference competition". While resource competition is considered to occur mainly for space, light and nutrients (Bartsch et al. 2008), interference competition is a consequence of chemical interactions between species, influencing the performance of competitors via allelopathy (Olson and Lubchenco 1990).

Previous investigations indicated the lack of multifactorial experiments (Wiencke et al. 2006) and the need to work with field material (Zacher et al. 2016) when evaluating the fate of unique polar ecosystems. Although temperature alone is not likely to endanger the performance of important Antarctic seaweeds (Müller et al. 2009), interaction with other factors such as irradiance and co-cultivation with other species may modify algal responses. Because of their natural zonation and geographical distribution, we hypothesise that $D$. menziesii can better cope with higher irradiance and temperature than $D$. anceps as it is occurring further north and in shallower water depth than the latter. Due to this reason, D. menziesii may have an advantage over $D$. anceps in the co-cultivation treatments under high-light and high-temperature conditions, possibly overgrowing $D$. anceps due to a better physiological adaptation. The major aim of this study was to investigate the effect of temperature or irradiance in combination with co-cultivation on the growth and photosynthetic performance of the two Antarctic macroalgae $D$. menziesii and $D$. anceps during their sporophytic life stage, under short-term exposure (approx. 2 weeks).

\section{Material and methods}

\section{Sampling site and algal material}

Experiments were carried out at the German-Argentinean Dallmann Laboratory, Carlini Station (Potter Cove) between 
January and March 2016. An overview of the abiotic and biotic conditions of the Potter Cove ecosystem is given in, e.g., Schloss et al. (2002b) and Deregibus et al. (2016). All algal material was collected from Area A1 ("Peñón de Pesca", $62^{\circ} 23^{\prime} \mathrm{S}, 58^{\circ} 72^{\prime} \mathrm{W}$; maps available in Deregibus et al. 2015) 1 to 2 days prior to the experiments, from $5 \mathrm{~m}$ depth by scuba divers. Adult sporophytes of the Phaeophyceae Desmarestia menziesii and D. anceps were collected with the holdfast and brought to the laboratory in dark boxes filled with seawater in order to avoid light stress during transport. Prior to the start of experiments, epiphytes were removed and individuals were kept in constantly aerated seawater containers, separated by species, under low irradiance conditions $\left(\sim 10 \mu \mathrm{mol} \mathrm{m} \mathrm{m}^{-2} \mathrm{~s}^{-1}\right)$ at $3 \pm 1{ }^{\circ} \mathrm{C}$. A day:night cycle of 16:8 $\mathrm{h}$ was applied prior and during each experiment to mimic local long-day conditions. Filtered seawater was exchanged daily. Experiments were conducted with the apical tips of both Desmarestia species (10-20 cm, cut around $1 \mathrm{~h}$ prior to the start of the acclimation phase).

\section{Experimental design}

Two experiments were carried out in a two-factorial design in order to assess the effects of temperature or irradiance on the different species and if these abiotic factors could alter possible competitive effects between the algae (Fig. 1). During the first experiment, the effect of (a) irradiance intensity (low, $\mathrm{LL}=10 \mu \mathrm{mol} \mathrm{m} \mathrm{m}^{-2} \mathrm{~s}^{-1} \mathrm{vs}$. high, $\mathrm{HL}=100 \mu \mathrm{mol} \mathrm{m} \mathrm{m}^{-2} \mathrm{~s}^{-1}$ ) and (b) culture treatment was tested over a period of 16 days. Desmarestia menziesii and $D$. anceps were both grown in mono- and in co-culture with the other species $(n=5)$. Temperature was set to $2{ }^{\circ} \mathrm{C}$. During the second experiment, the effect of (a) temperature $\left(2{ }^{\circ} \mathrm{C}=\right.$ ambient summer temperature vs. $7^{\circ} \mathrm{C}=$ global warming scenario) and (b) culture treatment was tested over a period of 11 days. As in the first experiment, D. menziesii and $D$. anceps were both grown in mono- and in co-culture $(n=5)$. Irradiance was set to $50 \mu \mathrm{mol} \mathrm{m}{ }^{-2} \mathrm{~s}^{-1}$ (Fig. 1).

Each replicate of a given treatment consisted of two sporophytes, which were grown in aerated 2-L plastic beakers and installed in four water baths controlled by thermostats (Variostat ${ }^{\circledR}$ CC, Huber, Germany). Each treatment consisted of five replicates. In the mono-culture, two sporophytes of the same species were added into each beaker, while in the co-culture one sporophyte of each species was added (Fig. 1). Temperature during each experiment was monitored via data loggers $\left(2.5 \pm 0.7\right.$ and $7.3 \pm 0.3{ }^{\circ} \mathrm{C}$; Hobo Pendant $\AA$ Temperature/Light Data Logger, USA). The beakers were filled with $0.22 \mu \mathrm{m}$ filtered seawater (Durapore ${ }^{\circledR}$ Cartridge Filter) with a salinity of 32 PSU (WTW Cond 3150i, Xylem Analytics, Weilheim, Germany). To avoid nutrient depletion and to inhibit diatom growth, seawater was enriched
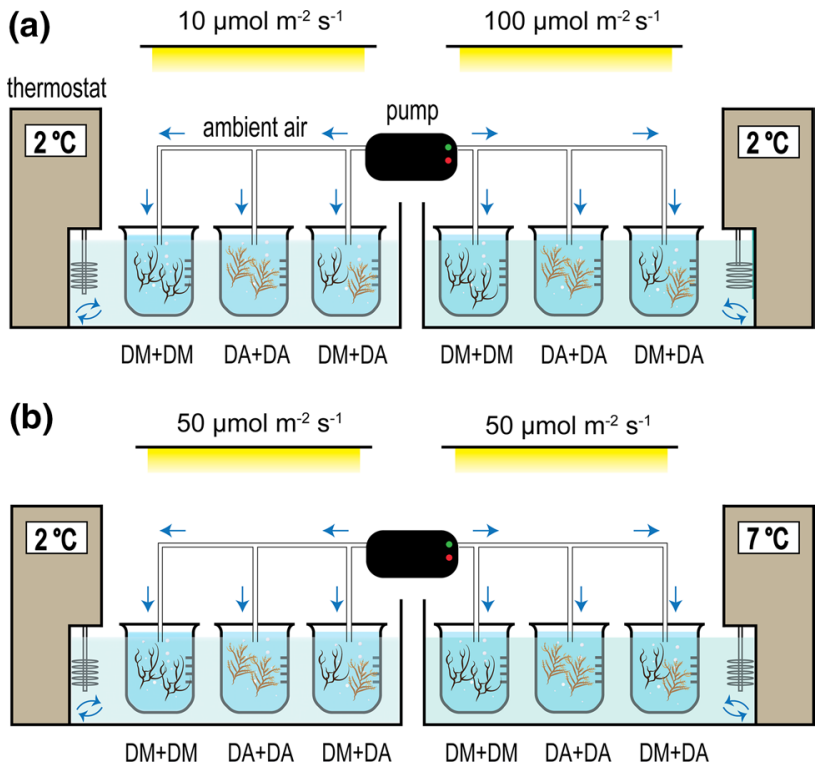

Fig. 1 Experimental design. a Experiment 1: Impact of co-cultivation and irradiance intensity on Desmarestia menziesii (DM) and D. anceps (DA): $10 \mu \mathrm{mol} \mathrm{m} \mathrm{m}^{-2} \mathrm{~s}^{-1}$ and $100 \mu \mathrm{mol} \mathrm{m} \mathrm{m}^{-2} \mathrm{~s}^{-1}$ were applied to both species mono- (DM, DA) and co-cultured (DM+DA) $(n=5)$ at $2{ }^{\circ} \mathrm{C}$ over 16 days with 4 days of acclimation to $10 \mu \mathrm{mol} \mathrm{m} \mathrm{m}^{-2} \mathrm{~s}^{-1}$. b Experiment 2: Impact of co-cultivation and temperature on $D$. menziesii and $D$. anceps: $2{ }^{\circ} \mathrm{C}$ and $7{ }^{\circ} \mathrm{C}$ were applied to both species mono- and co-cultured $(n=5)$; at $50 \mu \mathrm{mol} \mathrm{m} \mathrm{m}^{-2} \mathrm{~s}^{-1}$ over 11 days with 3 days of acclimation to the experimental conditions

with nutrients after Provasoli $(1968 ; 50 \mathrm{~mL}$ per $10 \mathrm{~L}$ of seawater) and with germanium dioxide $\left(0.5 \mathrm{~mL}\right.$ of $\mathrm{GeO}_{2}$ per litre of seawater as described by Shea and Chopin 2007). Media was changed weekly. Light was provided by halogen lamps (NORKA tipo Sirius HIT $150 \mathrm{~W}$, DörverdenHülsen, Hamburg, Germany). PAR was measured at the top of each beaker using a flathead LICOR 190 SA quantum sensor (cosine corrected) connected to a LICOR LI-1400 data logger (LICOR, Lincoln, USA). Prior to the start of the experiments, algae were acclimated to the experimental temperatures for 3 to 4 days. The irradiance was set according to field measurements performed on site where approx. 100 photons $\mu \mathrm{mol} \mathrm{m} \mathrm{m}^{-2} \mathrm{~s}^{-1}$ represents the mean irradiance intensity at $5 \mathrm{~m}$ depth during summer, while $50 \mu \mathrm{mol}$ photons $\mathrm{m}^{-2} \mathrm{~s}^{-1}$ represents the mean irradiance at $10 \mathrm{~m}$ depth (Campana et al. 2018). The biomass peak of D. menziesii is found at $5 \mathrm{~m}$ depth, whereas $D$. anceps has its biomass maximum at $10 \mathrm{~m}$ depth (Quartino et al. 2001).

\section{Algal growth and photosynthetic efficiency}

Growth rate and photosynthetic parameters were determined to document the effects of temperature, irradiance and coculturing treatments on macroalgae performance. 
Pre-experimental fresh weight $(F W, \mathrm{mg})$ was measured when the algal material was transferred into the beakers for acclimation (Day 4 and 3 for experiments 1 and 2, respectively). Subsequently, $F W$ was measured when the experiment started or one day earlier (initials), at the midpoint (Day 6 for both experiments) and at the endpoint of the experiment (Day 16 and 11 for experiments 1 and 2, respectively). Before weighing, the sporophytes were carefully blotted one by one with tissue paper (Sartorius CPA323S0CE, Germany). Overall growth rates from the initial measurements (initials) until the last day of the experiment were calculated as

Specific growth $\operatorname{rate}\left(\mu\right.$, day $\left.^{-1}\right)=100 \frac{\ln N_{t} N_{0}^{-1}}{t}$,

where $N_{0}$ is the initial FW, $N_{t}$ is the $F W$ on day $t$, and $t$ is the time period expressed in day (see also Wiencke and tom Dieck 1989).

In order to assess the baseline physiological performance, pre-experimental photosynthetic efficiency $\left(F_{\mathrm{v}} / F_{\mathrm{m}}\right)$ of each sporophyte was measured the day the algal material was transferred into the beakers for acclimation. After that, photosynthetic efficiency was measured on Day 0 (= initials), at the midpoint (Day 7 and 5 for experiments 1 and 2, respectively) and at the endpoint of the experiment (Day 15 and 10 for experiments 1 and 2, respectively). In vivo chlorophyll $a$ fluorescence of photosystem II (PSII) was determined as the maximum quantum yield of PSII $\left(F_{\mathrm{v}} / F_{\mathrm{m}}\right)$ using a modulation fluorometer (PAM 2100, Walz GmbH, Effeltrich, Germany) connected to a PC running PamWin ${ }^{\mathrm{TM}}$ software. At each measurement, the fibre optic was placed $\sim \mathrm{cm}$ below the apical tip of the sporophyte. After 3 min of dark adaption, a saturating light pulse $(0.8 \mathrm{~s} ; 600 \mathrm{~ms}$ completely saturating white light pulse) was applied and minimal $\left(F_{0}\right)$ and maximal $\left(F_{\mathrm{m}}\right)$ fluorescence were used to calculate the $F_{\mathrm{v}} / F_{\mathrm{m}}$ using the PAM software as

$F_{v} / F_{\mathrm{m}}=\left(F_{\mathrm{m}}-F_{0}\right) / F_{m}$.

Three minutes of dark incubation were chosen because no further increase in $F_{\mathrm{v}} / F_{\mathrm{m}}$ was measured in a pilot study after 3-, 5-, 7-, 10- and 15-min dark adaption, demonstrating 3 min to be sufficient to "open" all reactions centres of PSII.

Additionally, rapid light curves were determined (PAM 2100) right after measurements of $F_{\mathrm{v}} / F_{\mathrm{m}}$ at the initial, the midpoint and the endpoint. The effective PSII quantum yield $\left(\Phi P S I I=\left(F_{\mathrm{m}}^{\prime}{ }^{-} F_{\mathrm{t}}\right) /{F_{\mathrm{m}}^{\prime}}^{\prime}\right)$ for the illuminated samples was calculated measuring the steady-state fluorescence in light $\left(F_{\mathrm{t}}\right)$ and the maximum light-adapted fluorescence yield $\left(F_{\mathrm{m}}^{\prime}\right)$ of each sporophyte during a stepwise increasing actinic light intensity (from 0 to $402 \mu \mathrm{mol}$ photons $\mathrm{m}^{-2} \mathrm{~s}^{-1}$, every $20 \mathrm{~s}$ ). The light intensities applied by the PAM were corrected with a LI-COR LI-250A Light Meter. The effective quantum yield represents a sensitive indicator of photosynthetic performance and, thus, of the health of algae affected by stress exposure. Estimations of the relative electron transport rates of PSII (rETR) were calculated by multiplying the effective quantum yield of PSII with the corresponding light intensity $\left(E_{\mathrm{PAR}}=\right.$ irradiance in the PAR region; $\left.400-700 \mathrm{~nm}\right)$ as follows:

$r \mathrm{ETR}=\Delta F / F_{\mathrm{m}}^{\prime} * E_{\mathrm{PAR}}$.

Photosynthesis versus irradiance curves (P-E curves) with rETR as a function of the irradiance intensity (PAR) were fitted after the hyperbolic tangent model (Jassby and Platt 1976). From each curve, the maximum relative electron transport rate $\left(\mathrm{rETR}_{\max }\right)$, the electron transport efficiency $(\alpha)$, and the saturation irradiance for electron transport $\left(E_{\mathrm{k}}\right.$, calculated as the intercept between $\alpha$ and $\mathrm{rETR}_{\max }$ ) were calculated. These parameters show the photosynthetic performance of the algae under the different treatments and may be used to interpret photo-acclimation.

\section{Statistical analysis}

Means and standard deviations (SD) were calculated from five independent replicates per treatment $(n=5)$, each of which was the mean of two pseudo-replicates. Normal distribution of data was tested by the Shapiro-Wilk $W$ test. One-way or two-way analysis of variance (ANOVA) was conducted on pre-experimental $F W$ and $F_{\mathrm{v}} / F_{\mathrm{m}}$ to assess the similarity of the values within each species among the treatments prior to the experiments. Additionally, twoway ANOVA on pre-experimental $F W$ and $F_{\mathrm{v}} / F_{\mathrm{m}}$ was also conducted on mono-cultured $D$. menziesii and $D$. anceps to allow further comparison of the two species over time. Two-way analyses of variance with repeated measures (RMANOVA) were conducted to identify statistically significant differences of means of $F_{\mathrm{v}} / F_{\mathrm{m}}, \mathrm{rETR}$ max,$\alpha$ and $E_{\mathrm{k}}$ of $D$. anceps and $D$. menziesii separately and of only mono-cultured species together under irradiance/temperature and cocultivation treatments (two levels of each between-subjects factor called 'irradiance' or 'temperature' and 'co-cultivation'), considering the Mauchly's sphericity test (three levels of the within-subjects called 'time': initial, midpoint and endpoint; $\alpha=0.05$ ). Where Mauchleys test of sphericity was violated (RM-ANOVA; $\varepsilon<0.75$ ), a Greenhouse-Geisser $(\mathrm{G}-\mathrm{G})$ correction was applied. Homogeneity of variances was tested using Levene's Test. Post hoc multiple means comparisons were performed with a Tukey's honest significance difference (HSD) test. A 5\% significance level $(p=0.05)$ was applied in all statistical tests. All statistical analyses were run using the R statistical software R 3.5.0 (R 241 Development Core Team 2018). Graphics were generated with the ggplot2 package (v. 3.1.1). 


\section{Results}

\section{Experiment 1: impact of irradiance and co-culturing on Desmarestia menziesii and D. anceps}

Measurements of $F W$ from pre-experimental material (Day -4) of D. anceps showed a similar distributed weight among the different treatments. In contrast, D. menziesii had a significantly higher pre-experimental weight at the high irradiance $(1.86 \pm 0.06 \mathrm{~g})$ compared to the low irradiance treatment $(1.79 \pm 0.05 \mathrm{~g}$; two-way ANOVA, $F=7.23$, $p=0.02$ ). Both species showed very low overall growth rates-however significantly different from zero (onesample $t$ test, $p=0.003$ for $D$. menziesii and $p<0.0001$ for $D$. anceps) - and no significant differences in growth with different irradiance or culture treatments could be detected (Fig. 2a). $F W$ data are shown in Online Resources 1.

$F_{\mathrm{v}} / F_{\mathrm{m}}$ values from pre-experimental material (exposed to low irradiance, Day -4) of both species were similar among the different treatments (Table 1). During the experiment, $F_{\mathrm{v}} / F_{\mathrm{m}}$ of both species was significantly higher at low irradiance $\left(10 \mu \mathrm{mol} \mathrm{m} \mathrm{m}^{-2} \mathrm{~s}^{-1}\right)$ compared to the high irradiance treatment $\left(100 \mu \mathrm{mol} \mathrm{m} \mathrm{m}^{-2} \mathrm{~s}^{-1}\right)$ but no significant culture effect was observed throughout the experiments (Tables 1, 2, Fig. 3a). $F_{\mathrm{v}} / F_{\mathrm{m}}$ values dropped over time in the high irradiance treatment (by $10 \%$ in D. menziesii and 11\% in $D$. anceps between Day 0 and 15), but remained constantly high at low irradiances, resulting in a significant time*irradiance interaction for both species (Tables 1, 2, Fig. 3a).
Generally, $\mathrm{rETR}_{\max }$ and $E_{\mathrm{k}}$ were lower at low irradiances compared to high irradiances in both species, however, not always significant (Tables 1, 2, Fig. 3a). Both rETR $_{\max }$ and $E_{\mathrm{k}}$ of $D$. menziesii showed an interactive effect of time*culture (Table 2, Fig. 3a). While both values remained constant in the mono-culture, they increased at the midpoint in the co-culture and decreased at the endpoint (Tables 1, 2, Fig. 3a).

Comparing the photosynthetic performance of $D$. menziesii and D. anceps mono-cultured directly, $\mathrm{rETR}_{\max }, \alpha$ and $E_{\mathrm{k}}$ were significantly higher in $D$. menziesii compared to $D$. anceps (by 32,17 and $21 \%$, respectively) with lower values at low irradiances as described above for the single species effects (Tables 1,3 , Fig. 3a). $F_{\sqrt{v}} / F_{\mathrm{m}}$ values were similar between the two species throughout the experiment and dropped significantly under the high irradiance treatment, while remaining constant under the low irradiance treatment as explained above for the single species effects (Tables 1, 3, Fig. 3a).

\section{Experiment 2: impact of temperature and co-culturing on Desmarestia menziesii and $D$. anceps}

Measurements of $F W$ from pre-experimental material (Day -3) of D. menziesii and D. anceps showed a similar distributed weight among the different treatments. As in experiment 1 , both species showed very low overall growth rateshowever significantly different from zero (one-sample $t$ test, $p<0.0001$ for both $D$. menziesii and D. anceps)—and no

(b)

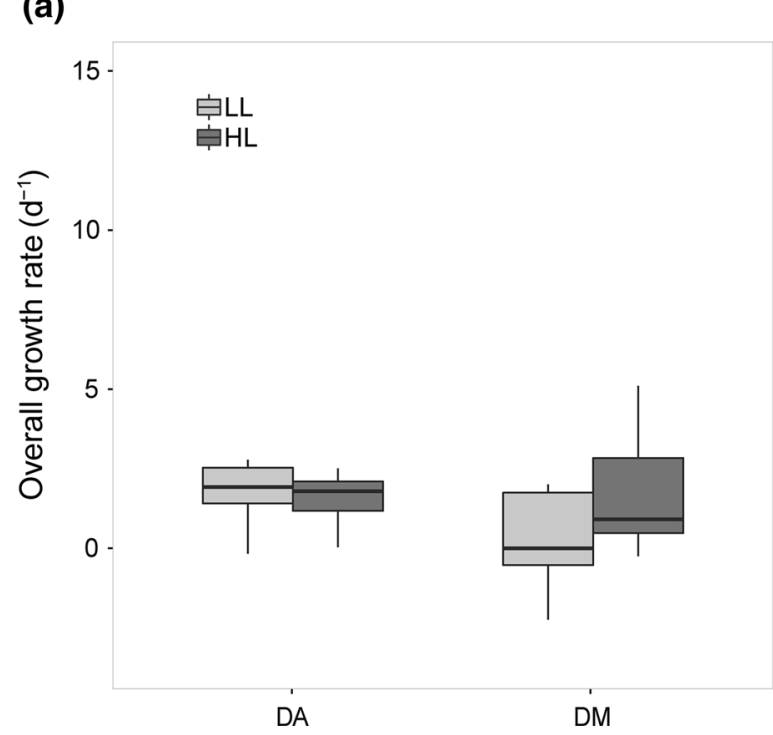

Fig. 2 Experiments 1 (a) and 2 (b): Box-whisker plots of overall growth rate (Day -1) of Desmarestia menziesii (DM) and D. anceps (DA), under 10 (LL) and $100 \mu \mathrm{mol} \mathrm{m}{ }^{-2} \mathrm{~s}^{-1}$ (HL, experiment 1 ) or at 2

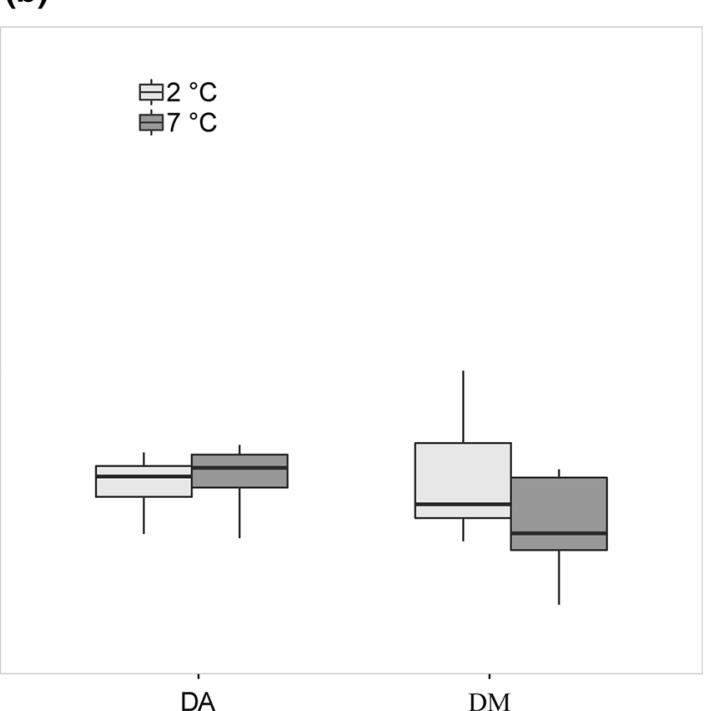

and $7{ }^{\circ} \mathrm{C}$ (experiment 2). Experimental duration: 16 days (experiment 1 ) and 11 days (experiment 2) (median \pm 95 to 5 percentile, $n=5)$ 


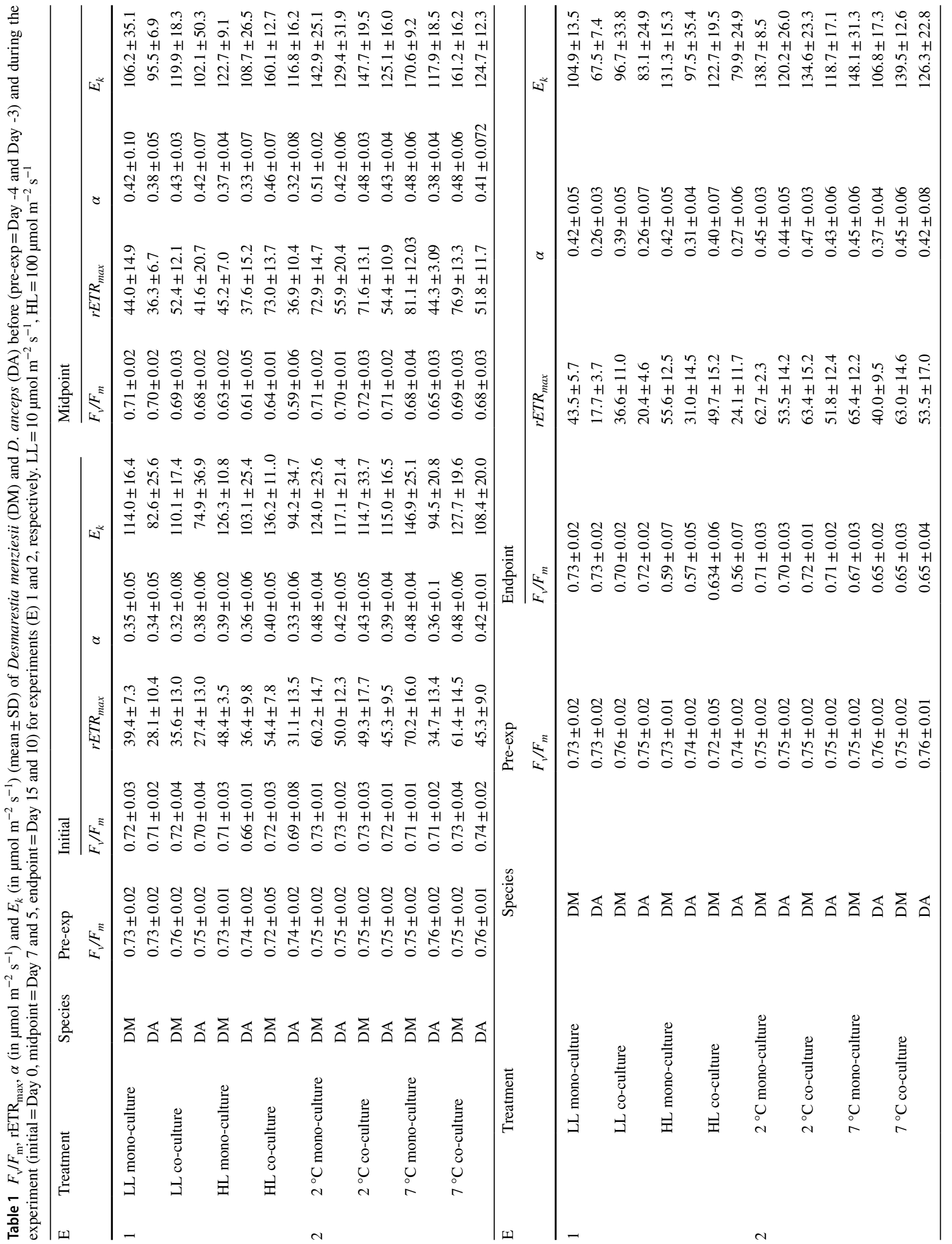


significant differences in growth with different irradiance or culture treatments could be detected (Fig. 2b). $F W$ data are shown in Online Resources 1.

$F_{\mathrm{v}} / F_{\mathrm{m}}$ values from pre-experimental material (Day -3) of both species were similar among the different treatments (Table 1). In general, $F_{\mathrm{v}} / F_{\mathrm{m}}$ of both species was higher at $2{ }^{\circ} \mathrm{C}$ compared to $7{ }^{\circ} \mathrm{C}$; however, a significant difference was detected for D. anceps only (Tables 1, 2; Fig. 3b). Both species showed a significant time*temperature effect on $F_{\mathrm{v}} /$ $F_{\mathrm{m}}$ due to a stronger decrease in $F_{\mathrm{v}} / F_{\mathrm{m}}$ at $7{ }^{\circ} \mathrm{C}$ compared to $2{ }^{\circ} \mathrm{C}$ over time (Tables 1, 2, Fig. 3b). Similar to the other experiment, no culture effect on $F / F_{\mathrm{m}}$ was observed for both species (Table 2).

Almost no significant effect on the other photosynthetic parameters was found for temperature or culture effects, and only $\mathrm{rETR}_{\max }$ of $D$. menziesii was significantly higher at $7{ }^{\circ} \mathrm{C}$ compared to $2{ }^{\circ} \mathrm{C}$ (Table 2 ).

Comparing the photosynthetic performance of D. menziesii and D. anceps mono-cultured directly, $\mathrm{rETR}_{\max }, \alpha$ and $E_{\mathrm{k}}$ were significantly higher in $D$. menziesii compared to D. anceps (by 48, 18 and 27\%, respectively), similarly to experiment 1 (Tables 1, 3, Fig. 3b). Both $r E T R_{\max }$ and $E_{\mathrm{k}}$ were lower at $7{ }^{\circ} \mathrm{C}$ compared to $2{ }^{\circ} \mathrm{C}$ in $D$. anceps, while it was the other way around for $D$. menziesii, resulting in a species*time interaction (Table 3 ). $F_{\mathrm{v}} / F_{\mathrm{m}}$ values were similar between the two species throughout the experiment showing a significant time*temperature effect due to a stronger decrease in $F_{\mathrm{v}} / F_{\mathrm{m}}$ at $7{ }^{\circ} \mathrm{C}$ compared to $2{ }^{\circ} \mathrm{C}$ over time as described above for the single species effects (Tables 1, 3, Fig. 3b).

\section{Discussion}

This study investigated whether direct or indirect effects of climate change may alter growth and photosynthetic performance of the two key macroalgal species in Antarctic coastal areas, $D$. menziesii and $D$. anceps. The tested factors were irradiance or temperature (abiotic) and co-culturing (biotic), including the interaction between these factors during short-term exposure (approx. 2 weeks). While no strong effects during co-culturing of the different species combinations were observed, temperature but mostly irradiance led to significant changes in the photosynthetic performance of the species.

Generally, growth of both Desmarestia species was too low to detect treatment effects. Wiencke and tom Dieck $(1989,1990)$ detected optimal growth rates for these species at temperatures $\leq 5{ }^{\circ} \mathrm{C}$, whereas Zacher et al. (2016) could show higher growth rates for $D$. anceps at $5{ }^{\circ} \mathrm{C}$ compared to $0{ }^{\circ} \mathrm{C}$ in a study with cultured material. Defined as season anticipators (Kain 1989; Wiencke 1990; Gómez and Wiencke 1997), D. menziesii and D. anceps start to grow only under short day conditions in late winter/ spring, even under the sea ice. They reach maximal growth rates in spring (September for D. anceps and December for $D$. menziesii) and have their minimum growth activity in summer to autumn (from January to May; Wiencke 1990; Gómez and Wiencke 1997). Our experiments—due to logistical constraints-took place in the Antarctic summer and unfortunately growth was very low due to the circannual growth rhythm of the two species, possibly masking treatment effects. However, not just season but also other factors such as age and size of the algae may influence growth rates, as it has been found in other studies (e.g. Khailov 1976; Wiencke 1990; Zacher et al. 2016). Current and modelled warming in Antarctica (Clark et al. 2013) does not seem to threaten the ecosystem builders $D$. anceps and D. menziesii as growth until $7{ }^{\circ} \mathrm{C}$ is not reduced compared to lower temperatures and material was healthy without any bleaching. Upper survival temperature (UST) of D. anceps is published to be around $11-12{ }^{\circ} \mathrm{C}$ (Wiencke and tom Dieck 1989). Preliminary results suggest that the UST of D. menziesii may be higher compared to D. anceps (Matula unpublished), which would also explain its broader distribution compared to $D$. anceps (Wiencke et al. 2014.).

\section{Irradiance effects on photosynthesis}

Not surprisingly, irradiance exerted the strongest effects on photosynthetic parameters of D. menziesii and $D$. anceps. $F_{\mathrm{v}} / F_{\mathrm{m}}$ in both species is significantly higher at $10 \mu \mathrm{mol} \mathrm{m}{ }^{-2} \mathrm{~s}^{-1}$ than at $100 \mu \mathrm{mol} \mathrm{m} \mathrm{s}^{-2} \mathrm{~s}^{-1}$, pointing to a light stress at the higher irradiance conditions. In contrast, $\mathrm{rERT}_{\max }$ and $E_{\mathrm{k}}$ are higher at 100 than at $10 \mu \mathrm{mol} \mathrm{m} \mathrm{s}^{-2}$, though only statistically significant in $D$. menziesii, pointing to acclimation to higher irradiance. The irradiance regime in Antarctica is highly variable-from complete darkness in winter under sea ice to maximum PAR values between 230 and $500 \mu \mathrm{mol} \mathrm{m} \mathrm{m}^{-2} \mathrm{~s}^{-1}$ (at 10 and $5 \mathrm{~m}$, respectively) in spring, under clear water conditions (Campana et al. 2018; Deregibus pers. comm.). Algal photosynthesis in Antarctica is therefore restricted from spring to autumn (Wiencke et al. 2009). Major seasonal adjustments of photosynthesis include changes in photosynthetic efficiency (initial slope, $\alpha$ ) and particularly the light requirements for saturation $\left(E_{\mathrm{k}}\right)$ (Gómez et al. 2009, 2019; Wiencke et al. 2009). Both Desmarestia species showed a high acclimation potential to these changing environmental light conditions in our study. $E_{\mathrm{k}}$ values measured were well above $100 \mu \mathrm{mol} \mathrm{m}^{-2} \mathrm{~s}^{-1}$ for both species and all treatments, which is higher than most published values. Weykam et al. (1996) measured $E_{k}$ values of 32 and $30 \mu \mathrm{mol} \mathrm{m}^{-2} \mathrm{~s}^{-1}$ for D. anceps and D. menziesii, respectively, whereas Gómez et al. (2009) reviewed values between 31 and $105 \mu \mathrm{mol} \mathrm{m} \mathrm{m}^{-2} \mathrm{~s}^{-1}$. In another study, 


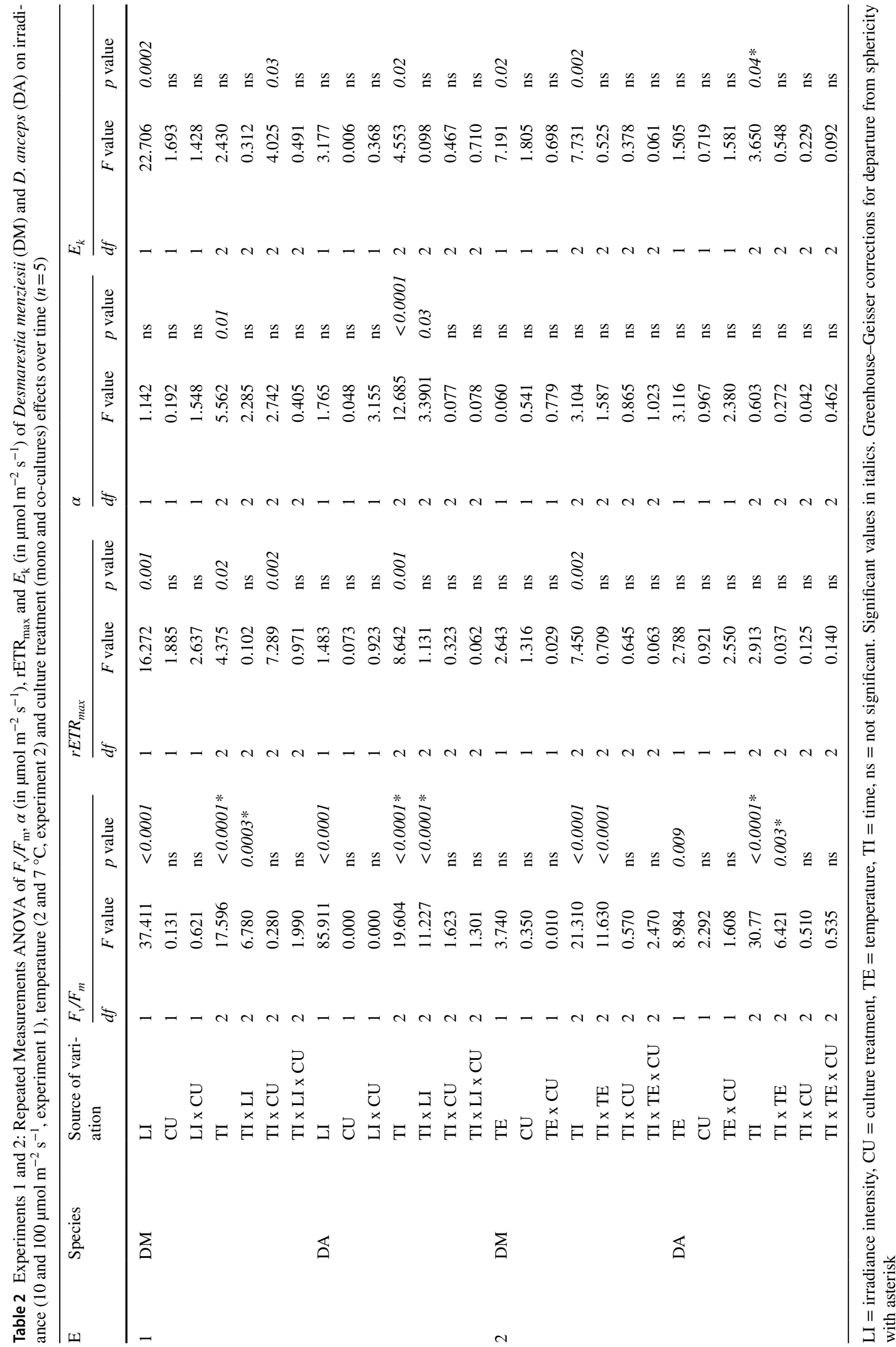

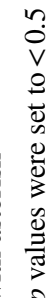


Table 3 Experiments 1 and 2: Repeated Measurements ANOVA

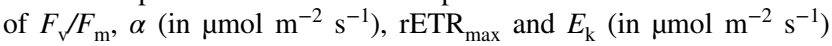
of Desmarestia menziesii (DM) and D. anceps (DA) mono-cultured

\begin{tabular}{|c|c|c|c|c|c|c|c|c|c|c|c|c|c|c|}
\hline \multirow[t]{2}{*}{ Species } & \multirow[t]{2}{*}{$\mathrm{E}$} & \multirow[t]{2}{*}{ Source of variation } & \multicolumn{3}{|c|}{$F_{v} / F_{m}$} & \multicolumn{3}{|c|}{$r E T R_{\max }$} & \multicolumn{3}{|l|}{$\alpha$} & \multicolumn{3}{|l|}{$E_{k}$} \\
\hline & & & $d f$ & $F$ value & $p$ value & $d f$ & $F$ value & $p$ value & $d f$ & $F$ value & $p$ value & $d f$ & $F$ value & $p$ value \\
\hline \multirow[t]{14}{*}{$\mathrm{DM}+\mathrm{DA}$ mono-cultured } & \multirow[t]{7}{*}{1} & SP & 1 & 3.048 & ns & 1 & 29.28 & $<0.0001$ & 1 & 15.73 & 0.001 & 1 & 22.12 & 0.0007 \\
\hline & & LI & 1 & 63.29 & $<0.0001$ & 1 & 7.35 & 0.015 & 1 & 0.018 & ns & 1 & 9.18 & 0.004 \\
\hline & & $\mathrm{TI}$ & 1 & 31.79 & 0.0001 & 1 & 3.84 & ns* & 1 & 10.67 & $0.009 *$ & 1 & 0.569 & ns \\
\hline & & $\mathrm{SP} \times \mathrm{LI}$ & 1 & 0.696 & ns & 1 & 0.001 & ns & 1 & 0.100 & ns & 1 & 0.070 & ns \\
\hline & & $\mathrm{TI} \times \mathrm{LI}$ & 2 & 29.22 & $<0.0001$ & 2 & 1.90 & ns & 2 & 5.67 & ns* & 2 & 0.231 & ns \\
\hline & & $\mathrm{TI} \times \mathrm{SP}$ & 2 & 1.50 & ns & 2 & 1.75 & ns & 2 & 0.855 & ns & 2 & 1.97 & ns \\
\hline & & $\mathrm{TI} \times \mathrm{LI} \times \mathrm{SP}$ & 2 & 1.27 & ns & 2 & 0.177 & ns & 2 & 0.012 & ns & 2 & 0.523 & ns \\
\hline & \multirow[t]{7}{*}{2} & SP & 1 & 2.05 & ns & 1 & 54.06 & $<0.0001$ & 1 & 58.24 & 0.0002 & 1 & 29.48 & 0.0002 \\
\hline & & $\mathrm{TE}$ & 1 & 14.42 & $<0.0001$ & 1 & 0.088 & ns & 1 & 3.545 & 0.03 & 1 & 0.088 & ns \\
\hline & & TI & 1 & 54.14 & $<0.0001$ & 1 & 3.344 & 0.02 & 1 & 0.481 & ns & 1 & 3.42 & 0.03 \\
\hline & & $\mathrm{SP} \times \mathrm{TE}$ & 1 & 0.440 & ns & 1 & 1.26 & 0.02 & 1 & 4.782 & ns & 1 & 9.89 & 0.01 \\
\hline & & $\mathrm{TI} \times \mathrm{TE}$ & 2 & 5.06 & ns & 2 & 0.115 & ns & 2 & 0.005 & ns & 2 & 0.249 & ns \\
\hline & & $\mathrm{TI} \times \mathrm{SP}$ & 2 & 2.11 & ns & 2 & 11.25 & ns & 2 & 4.782 & ns & 2 & 0.051 & ns \\
\hline & & $\mathrm{TI} \times \mathrm{TE} \times \mathrm{SP}$ & 2 & 0.47 & $\mathrm{~ns}$ & 2 & 0.29 & ns & 2 & 0.829 & ns & 2 & 0.467 & $\mathrm{~ns}$ \\
\hline
\end{tabular}

$p$ values were set to $<0.5$

$\mathrm{SP}=$ Species $($ D. menziesii and D. anceps $), \mathrm{LI}=\operatorname{Light}\left(10\right.$ and $100 \mu \mathrm{mol} \mathrm{m} \mathrm{m}^{-2} \mathrm{~s}^{-1}$, experiment 2$)$, TE $=$ Temperature $\left(2\right.$ and $7{ }^{\circ} \mathrm{C}$, experiment 3$)$, $\mathrm{TI}=$ time, $\mathrm{ns}=$ not significant. Significant values in italics. Greenhouse-Geisser corrections for departure from sphericity with asterisk

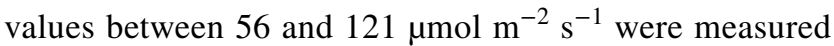
for the two Desmarestia species, approaching the values we observed (Gómez et al. 2019). Furthermore, Schoenrock et al. (2015) measured $E_{\mathrm{k}}$ values similar and even higher than in our study, between 130 and $220 \mu \mathrm{mol} \mathrm{m} \mathrm{m}^{-2} \mathrm{~s}^{-1}$. Interestingly, the in situ measurements taken in the field were only slightly higher than our findings (167 for D. menziesii and 141 for $D$. anceps). Variations with other studies can be due to three main reasons: (1) difference in the methodology: Weykam et al. (1996), Gómez et al. (1995) and Gómez and Wiencke (1997), for example, measured and calculated the $E_{k}$ values using oxygen measurements via an optode, while the other studies used a fluorometer. (2) Season: as stated above, photosynthesis is highly seasonal in Antarctic macroalgae. Whereas Weykam et al. (1996) and Gómez and Wiencke (1997) measured field material sampled in austral spring, summer material was used in our study and in the study of Gómez et al. (2019) and Schoenrock et al. (2015). This material had a long time under high irradiance conditions to adjust its photosynthesis. (3) Sampling depth: It was shown by Gómez and Wiencke (1997) and Rautenberger et al. (2015) that especially $D$. anceps shows decreasing $E_{\mathrm{k}}$ values with depth. In this study, $D$. anceps was sampled at its upper distribution limit of $5 \mathrm{~m}$. At this depth, Rautenberger et al. (2015) measured an $E_{\mathrm{k}}$ of $80 \mu \mathrm{mol} \mathrm{m}{ }^{-2} \mathrm{~s}^{-1}$, whereas at $15 \mathrm{~m}$ it was $50 \%$ less. Comparing our data to culture material, which was held in stock cultures under low irradiance conditions for many years, the differences during experiments 1 and 2 on species, irradiance and temperature effects over time $(n=5)$ 
(a)
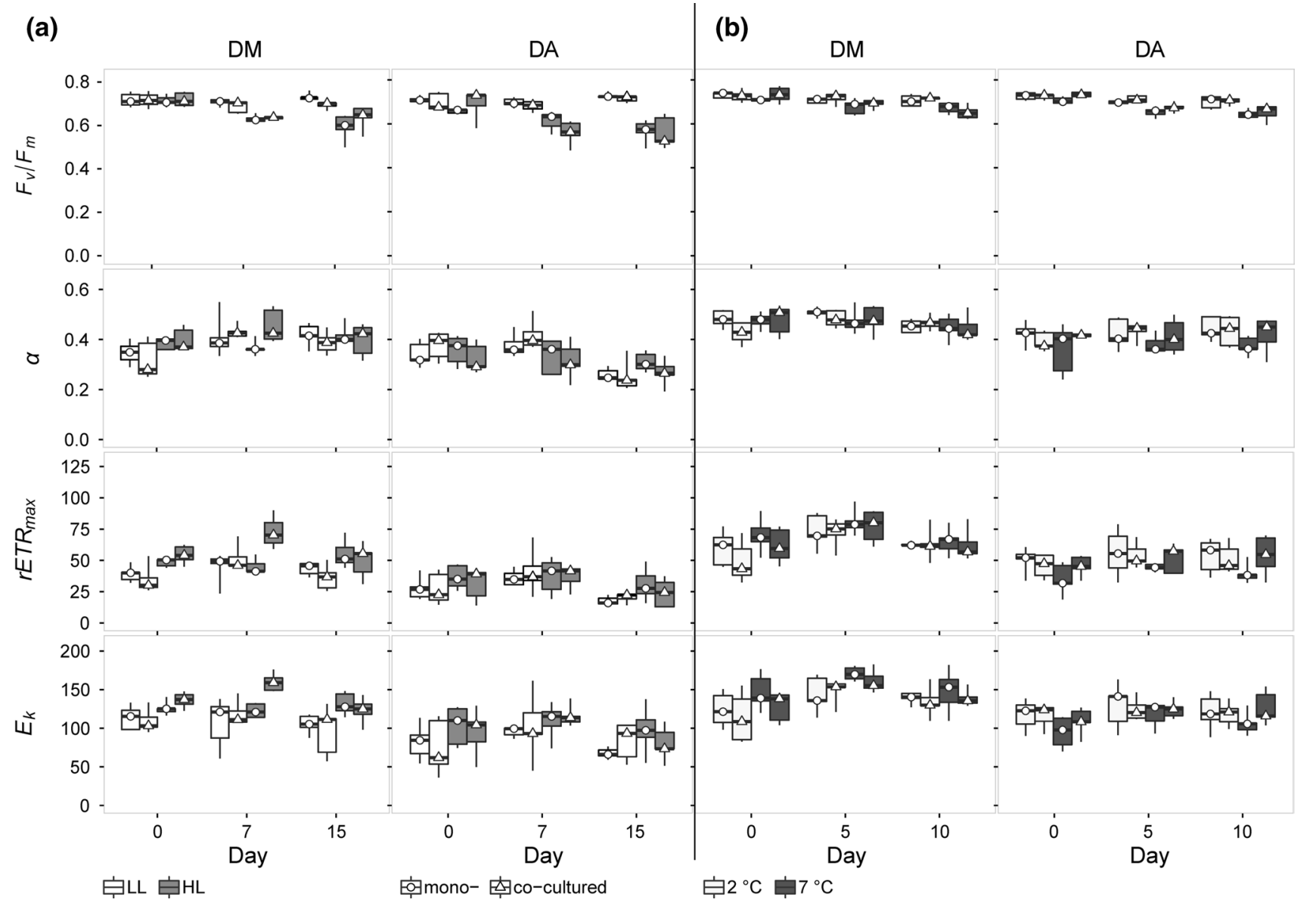

Fig. 3 Experiments 1 (a) and 2 (b): Box-whisker plots of maximum quantum yield $\left(F_{\mathrm{v}} / F_{\mathrm{m}}\right), \alpha$ (in $\left.\mu \mathrm{mol} \mathrm{m} \mathrm{m}^{-2} \mathrm{~s}^{-1}\right), \mathrm{rETR}_{\max }$ and $E_{\mathrm{k}}$ (in $\mu \mathrm{mol}$ $\mathrm{m}^{-2} \mathrm{~s}^{-1}$ ) of Desmarestia menziesii (DM) and D. anceps (DA) mono-

effective electron transport). Although both species are characterised as strongly shade adapted (revised in Gómez et al. 2009), they can also cope well with enhanced irradiance conditions occurring during Austral spring and summer. As for growth, a strong seasonal pattern of photosynthetic performance of macroalgae has been found as well in long-term studies (Weykam and Wiencke 1996; Gómez and Wiencke 1997; Weykam et al. 1997; Lüder et al. 2001, 2002) and in field experiments (Gutkowski and Maleszewski 1989; Drew and Hastings 1992; Gómez et al. 1995, 1997).

\section{Temperature effects on photosynthesis}

$F_{\mathrm{v}} / F_{\mathrm{m}}$ was higher at $2{ }^{\circ} \mathrm{C}$ compared to $7{ }^{\circ} \mathrm{C}$ in $D$. anceps and $D$. menziesii (although not always significantly). $E_{\mathrm{k}}$ values, on the other hand, were higher at $7^{\circ} \mathrm{C}$ than at $2{ }^{\circ} \mathrm{C}$ in D. menziesii. Furthermore, $F_{\mathrm{v}} / F_{\mathrm{m}}$ decreased over time in the $7{ }^{\circ} \mathrm{C}$ treatment, while it did not in the $2{ }^{\circ} \mathrm{C}$ treatment. The higher $F_{\mathrm{v}} / F_{\mathrm{m}}$ values at lower temperatures are in contrast to experiments with cultured material of $D$. menziesii cultured and co-cultured under 10 (LL) and $100 \mu \mathrm{mol} \mathrm{m}^{-2} \mathrm{~s}^{-1}$ (HL, experiment 1 ) or at 2 and $7{ }^{\circ} \mathrm{C}$ (experiment 2) (median \pm 95 to 5 percentile, $n=5$ )

and $D$. anceps where $F_{\mathrm{v}} / F_{\mathrm{m}}$ was higher at 5 compared to $0{ }^{\circ} \mathrm{C}$ (Zacher et al. 2016). However, the $E_{\mathrm{k}}$ values showed the same trend, with higher values at higher temperatures (Zacher et al. 2016). While variation in the temperatures used in previous experiments renders a direct comparison difficult, a just $2{ }^{\circ} \mathrm{C}$ difference reversed the effect of the study of Zacher et al. (2016) and demonstrates again the strong cold-water adaptation of these alga (Gómez et al. 2009). Antarctic seaweeds have been shown to exhibit $P_{\max }$ values at $0{ }^{\circ} \mathrm{C}$ as high as temperate seaweeds measured at higher temperatures (Wiencke et al. 1993) due to a variety of adaptations to cold temperatures such as (i) unsaturated fatty acids that maintain the fluidity of the membranes, (ii) molecular adaptations of the enzymes to the cold, (iii) cold shock and antifreeze proteins and (iv) adaptations of the electron transport chain (reviewed in Morgan-Kiss et al. 2006). Although Antarctic macroalgae are strong coldwater-adapted species, it has also been shown that their optima for photosynthesis lie above the temperature of their natural environment at least in cultured algae (Wiencke et al. 
1993; Gómez et al. 2009). This effect was not detectable in our experiment, as $F_{\mathrm{v}} / F_{\mathrm{m}}$ is higher under colder temperature and $\mathrm{rETR}_{\max }$ was not affected by temperature. These observed differences may be due in part to the fact that field material and not culture material from long-time stock cultures was used, as well as interactive effects with other factors. Rautenberger et al. (2015), for example, did not find any difference in $F_{\mathrm{v}} / F_{\mathrm{m}}$ in D. anceps and D. menziesii derived from field material comparing 2 and $7{ }^{\circ} \mathrm{C}$ treatment under short time exposure (22 h). Also Schoenrock et al. (2015) did not find strong differences in photosynthetic parameters of D. anceps and D. menziesii from field material exposed to 1.5 and $3.5{ }^{\circ} \mathrm{C}$, supporting the idea that field material may react differently than culture material. Gómez et al. (2019) detected a small, but not significant reduction in $F_{\mathrm{v}} /$ $F_{\mathrm{m}}$ while exposing both Desmarestia species to UV radiation (UVR; $280-400 \mathrm{~nm}$ ) and $7{ }^{\circ} \mathrm{C}$ compared to a control treatment without UVR and $2{ }^{\circ} \mathrm{C}$. Using culture material, Zacher et al. (2016) detected an initial synergistic effect of high temperature $\left(5^{\circ} \mathrm{C}\right)$ and high irradiance $\left(50 \mu \mathrm{mol} \mathrm{m}{ }^{-2} \mathrm{~s}^{-1}\right)$ leading to lower $F_{\mathrm{v}} / F_{\mathrm{m}}$ which disappeared during the second week of the experiment. Moreover, $\mathrm{rETR}_{\max }$ of D. menziesii decreased stronger at lower temperatures $\left(0{ }^{\circ} \mathrm{C}\right)$ than at $5{ }^{\circ} \mathrm{C}$, whereas $D$. anceps sporophytes responded in the opposite way. Also for the Arctic kelp Saccharina latissima (Heinrich 2016), the highest stress response was found for the combination of high temperature with high irradiance. Our experiments with field material were only run over 11 to 16 days, thus raising the possibility that high irradiance $\left(100 \mu \mathrm{mol} \mathrm{m}^{-2} \mathrm{~s}^{-1}\right)$ in combination with higher temperatures led to a higher stress response of the algae compared to $2{ }^{\circ} \mathrm{C}$ and low light.

It is also postulated that brown algae with intermittent growth phases characterised by periods of growth followed by periods of rest over one year (Lüning and tom Dieck 1989), such as Laminariales, Fucales or Antarctic Desmarestiales (Wiencke 1990; Gómez and Wiencke 1997), may exhibit seasonally different temperature affinities (Zacher et al. 2016). For example, temperate brown algae of the order Laminariales and Desmarestiales were more susceptible to high temperatures during late winter compared to summer or in actively growing tissue compared to old tissue (Lüning 1984). In a recent seasonal benthocosm study on the temperate brown alga Fucus vesiculosus, Graiff et al. (2015) showed how major temperature effects were stronger during the active growth phase. This is of special interest in Antarctica where winter temperatures have been rising more than summer temperatures (Schloss et al. 2012). The large brown species of the order Desmarestiales thus have to endure a long dark winter period initiating growth during late winter by using the storage compounds built-up during spring-autumn.

\section{Differences in the photosynthetic performance between Desmarestia menziesii and D. anceps}

Comparing $F_{\mathrm{v}} / F_{\mathrm{m}}$ of $D$. anceps and $D$. menziesii monocultured, no difference was detected. It was generally above 0.7 under non-stressful conditions, very similar to values measured in other studies (Rautenberger et al. 2015; Schoenrock et al. 2015). However, $\mathrm{rETR}_{\max }, E_{\mathrm{k}}$ and $\alpha$ were always higher in $D$. menziesii than in $D$. anceps, irrespective of the temperature or irradiance applied. In particular, the higher $\mathrm{rETR}_{\max }$ and $E_{\mathrm{k}}$ values in D. menziesii (in some cases double) compared to $D$. anceps may explain, at least partly, the dominance of the first species over the latter in shallower habitats. While D. menziesii is dominant around $5 \mathrm{~m}, D$. anceps dominates at $10 \mathrm{~m}$ (Quartino et al. 2001). Desmarestia menziesii needs more light to saturate its photosynthesis but may use all this energy to build up biomass, whereas D. anceps seems to be more shade adapted. Unfortunately, we could not confirm this with the growth measurements (see above) and no comparable growth data for both species under high irradiance exist as most studies applied low irradiances $<20 \mu \mathrm{mol} \mathrm{m}^{-2} \mathrm{~s}^{-1}$ (Rautenberger et al. 2015; Schoenrock et al. 2015). Young sporophytes of D. anceps were shown to grow well under $50 \mu \mathrm{mol} \mathrm{m} \mathrm{m}^{-2} \mathrm{~s}^{-1}$ (Wiencke and tom Dieck 1989) but no comparative studies with $D$. menziesii exist to our knowledge. However, both species are able to adjust their photosynthetic performance very fast to different irradiance conditions as stated above.

\section{Effects of co-culturing}

No co-culturing effects on growth nor on photosynthetic parameters between $D$. menziesii and $D$. anceps occurred in combination with different temperatures and irradiance regimes. The same result was found in a similar study performed with cultured material, where $D$. menziesii and $D$. anceps were mono- and co-cultured under different temperatures (Zacher et al. 2016). Although the outcome of these experiments did not show any co-culturing effect between these species, competition may occur on a different time scale (longer experimental time) or in different life-cycle stages and/or under different environmental conditions (Carpenter 1990; Coelho et al. 2000; Barner et al. 2016; Traiger and Konar 2017). Nabivailo et al. (2014) and Xu et al. (2013) conducted experiments with different life-cycle stages (gametophytes, adult thalli) and showed both negative and positive interactions. In Arctic kelps, competition occurs during early recruitment (gametophyte and young sporophyte stage) and can be altered by the temperature regime depending on the temperature optima of the competing species. Generally, early developmental stages, such as young sporophytes, seem to be affected by 
biotic or abiotic alterations in a species-specific manner (Zacher et al. 2016); therefore in future studies, different life-stages of our tested algae and longer experimental durations need to be taken into account.

\section{Conclusion}

Although a temperature increase of $7{ }^{\circ} \mathrm{C}$ in summer is not lethal for $D$. menziesii and $D$. anceps sporophytes, the higher temperature exerted a stress response on their photosynthetic efficiency in combination with irradiance intensities encountered under field conditions (50 to $100 \mu \mathrm{mol} \mathrm{m} \mathrm{m}^{-2} \mathrm{~s}^{-1}$ ). Sporophytes of $D$. menziesii show better physiological abilities to cope with high temperature and irradiance regimes compared to $D$. anceps ones, as a confirmation of our initial hypothesis. However, no co-cultivation effect was found in this study within the two species, possibly due to the low growth rates of both species. Future experiments need to take into consideration the combined effects of other relevant factors (such as temperature, irradiance, nutrients, competition and grazing), which may act in a synergistic or antagonistic way over different time spans (short- and long-term exposure). Further investigations on all life-cycle stages (spores, gametophytes, young and adult sporophytes), reproduction (e.g. gametogenesis) and in different seasons would be important to generate a more complete picture and to better understand the effects of these threats on species and macroalgal assemblages in general. The seasonal aspect is of particular concern because these algae mainly grow in late winter/spring when temperature rise through global warming is highest (Schloss et al. 2012). Contrasting results between laboratory and field material experiments (Wiencke and tom Dieck 1989; Rautenberger et al. 2015; Zacher et al. 2016) highlight the need for more field-based research and show that care must be taken in extrapolating small-scale laboratory experiments to the community level.

Acknowledgements We would like to thank the diving and logistic team at Dallmann/ Carlini Sation. This work was supported by the Deutsche Forschungsgemeinschaft (DFG) in the framework of the priority programme "Antarctic Research with comparative investigations in Arctic ice areas" by a Grant Za735/1-1, by the Alfred-WegenerInstitute Helmholtz Centre for Polar and Marine Research and the international Research Network IMCONet funded by the Marie Curie Action IRSES IMCONet (FP7 IRSES - International Research Staff Exchange Scheme, Action No. 319718). We thank also Jilda Caccavo and Dina Brode-Roger for suggestions on language aspects and Dieter Piepenburg and the three anonymous reviewers for the helpful comments on the manuscript.

\section{Compliance with ethical standards}

Conflict of interest The authors declare that they have no conflict of interest.

\section{References}

Amsler CD, Rowley RJ, Laur DR, Quetin LB, Ross RM (1995) Vertical distribution of Antarctic peninsular macroalgae: cover, biomass and species composition. Phycologia 34(5):424-430

Barner AK, Hacker SD, Menge BA, Nielsen KJ (2016) The complex net effect of reciprocal interactions and recruitment facilitation maintains an intertidal kelp community. J Ecol 104:33-43

Barrera-Oro E, Moreira E, Seefeldt MA, Francione MV, Quartino ML (2018) The importance of macroalgae and associated amphipods in the selective benthic feeding of sister rockcod species Notothenia rossii and $N$ coriiceps (Nototheniidae) in West Antarctica. Polar Biol 42(2):317-334

Bartsch I, Wiencke C, Bischof K, Buchholz CM, Buck BH, Eggert A, Feuerpfeil P, Hanelt D, Jacobsen S, Karez R, Karsten U, Molis M, Roleda MY, Schubert H, Schumann R, Valentin K, Weinberger F, Wiese J (2008) The genus Laminaria sensu lato: recent insights and developments. Eur J Phycol 43:1-86

Bartsch I, Wiencke C, Laepple C (2012) Global seaweed biogeography under a changing climate: the prospected effects of temperature. In: Wiencke C, Bischof K (eds), Seaweed biology: novel insights into ecophysiology, ecology and utilization. Heidelberg: Springer

Brouwer PEM (1996) Decomposition in situ of the sublittoral Antarctic macroalga Desmarestia anceps Montagne. Polar Biol 16:129-137

Campana GL, Zacher K, Deregibus D, Momo FR, Wiencke C, Quartino ML (2018) Long term succession of benthic algae in Antarctica: structural patterns and glacial impact. Polar Biol 41(2):377-396

Carlsen BP, Johnsen G, Berge J, Kuklinski P (2007) Biodiversity patterns of macro-epifauna on different lamina parts of Laminaria digitata and Saccharina latissima collected during spring and summer 2004 in Kongsfjorden, Svalbard. Polar Biol 30(7):939-943

Carpenter RC (1990) Competition among marine macroalgae: a physiological perspective. J Phycol 26:6-12

Clarke A, Murphy EJ, Meredith MP, King JC, Peck LS, Barnes DK, Smith RC (2006) Climate change and the marine ecosystem of the western Antarctic Peninsula. Philos Trans R Soc B 362(1477):149-166

Clark GF, Stark JS, Johnston EL, Runcie JW, Goldsworthy PM, Raymond B, Riddle MJ (2013) Light-driven tipping points in polar ecosystems. Glob Change Biol 19(12):3749-3761

Clayton MN (1994) Evolution of the Antarctic marine benthic algal flora. J Phycol 30:897-904

Chen B, Zou D, Jiang H (2015) Elevated CO2 exacerbates competition for growth and photosynthesis between Gracilaria lemaneiformis and Ulva lactuca. Aquaculture 443:49-55

Coelho SM, Rijstenbil JW, Brown MT (2000) Impacts of anthropogenic stresses on the early development stages of seaweeds. J Aquat Ecosyst Stress Recov 7:317-333

Cordone G, Marina TI, Salinas V, Doyle SR, Saravia LA, Momo FR (2018) Effects of macroalgae loss in an Antarctic marine food web: applying extinction thresholds to food web studies. Peer $\mathbf{J}$ 6:e5531

Cook AJ, Fox AJ, Vaughan DG, Ferrigno JG (2005) Retreating glacier fronts on the Antarctic Peninsula over the past half-century. Science 308(5721):541-544 
Deregibus D, Scharf FK, Pasotti F, Ruiz Barlett E, Servetto N, Abele D (2015) IMCONet Research Areas Map of Potter Cove, KingGeorge Island (I. 25 de Mayo), with links to maps. Instituto Antártico Argentino, Buenos Aires, Argentina. https://doi. org/10.1594/PANGAEA.853859.

Deregibus D, Quartino ML, Campana GL, Momo FR, Wiencke C, Zacher K (2016) Photosynthetic light requirements and vertical distribution of macroalgae in newly ice-free areas in Potter Cove, South Shetland Islands, Antarctica. Polar Biol 39(1):153-166

Drew EA, Hastings RM (1992) A year-round ecophysiological study of Himantothallus grandifolius (Desmarestiales, Phaeophyta) at Signy Island, Antarctica. Phycologia 31(3-4):262-277

Ducklow HW, Fraser WR, Meredith MP, Stammerjohn SE, Doney SC, Martinson DG, Sailley SF, Schofield OM, Steinberg DK, Venables HJ, Amsler CD (2013) West Antarctic Peninsula: an ice-dependent coastal marine ecosystem in transition. Oceanography 26:190-203

Gómez I, Wiencke C, Weykam G (1995) Seasonal photosynthetic characteristics of Ascoseira mirabilis (Ascoseirales, Phaeophyceae) from King George Island, Antarctica. Mar Biol 123(1):167-172

Gómez I, Wiencke C (1997) Seasonal growth and photosynthetic performance of the Antarctic macroalga Desmarestia menziesii (Phaeophyceae) cultivated under fluctuating Antarctic daylengths. Bot Acta 110(1):25-31

Gómez I, Wulff A, Roleda MY, Huovinen P, Karsten U, Quartino ML, Dunton K, Wiencke C (2009) Light and temperature demands of marine benthic microalgae and seaweeds in polar regions. Bot Mar 52:593-608

Gómez I, Navarro NP, Huovinen P (2019) Bio-optical and physiological patterns in Antarctic seaweeds: a functional trait based approach to characterize vertical zonation. Prog Ocean 174:17-27

Graiff A, Liesner D, Karsten U, Bartsch I (2015) Temperature tolerance of western Baltic Sea Fucus vesiculosus - growth, photosynthesis and survival. J Exp Mar Biol Ecol 471:8-16

Gutkowski R, Maleszewski S (1989) Seasonal changes of the photosynthetic capacity of the Antarctic macroalga Adenocystis utricularis (Bory) Skottsberg. Polar Biol 10(2):145-148

Hapter R, Wozniak B, Dobrowolski K (1983) Primary production in Ezcurra Inlet during the Antarctic summer of 1977/78. Oceanologia 15:175-184

Heinrich S (2016) Short term physiological response to light, UVR and temperature stress in Antarctic versus Arctic habitat structuring brown algae. Algological Stud 151(1):151-165

Huang YM, Amsler MO, McClintock JB, Amsler CD, Baker BJ (2007) Patterns of gammarid amphipod abundance and species composition associated with dominant subtidal macroalgae along the western Antarctic Peninsula. Polar Biol 30:1417-1430

IPCC (2018) Summary for Policymakers. In: Masson-Delmotte V, Zhai P, Pörtner HO, Roberts D, Skea J, Shukla PR, Pirani A, Moufouma-Okia W, Pean C, Pidcock R, Connors S, Matthews JBR, Chen Y, Zhou X, Gomis MI, Lonnoy E, Maycock T, Tignor $\mathrm{M}$, Waterfield $\mathrm{T}$ (eds.) Global warming of $15^{\circ} \mathrm{C}$ An IPCC Special Report on the impacts of global warming of $15^{\circ} \mathrm{C}$ above pre-industrial levels and related global greenhouse gas emission pathways, in the context of strengthening the global response to the threat of climate change, sustainable development, and efforts to eradicate poverty World Meteorological Organization, Geneva, p 32

Jassby AD, Platt T (1976) Mathematical formulation of the relationship between photosynthesis and light for phytoplankton. Limnol Oceanogr 21:540-547

Karsten U, Wulff A, Roleda MY, Müller R, Steinhoff FS, Fredersdorf J, Wiencke C (2009) Physiological responses of polar benthic algae to ultraviolet radiation. Bot Mar 52:639-654
Kain JM (1989) The seasons in the subtidal. Br Phycol J 24(3):203-215

Khailov KM (1976) The relationships between weight, length, age and intensity of photosynthesis and organotrophy of macrophytes in the Barents Sea. Bot Mar 19(6):335-340

Klöser H, Quartino ML, Wiencke C (1996) Distribution of macroalgae and macroalgal communities in gradients of physical conditions in Potter Cove, King George Island, Antarctica. Hydrobiologia 333(1):1-17

Lüder UH, Knoetzel J, Wiencke C (2001) Acclimation of photosynthesis and pigments to seasonally changing light conditions in the endemic Antarctic red macroalga Palmaria decipiens. Polar Biol 24(8):598-603

Lüder UH, Wiencke C, Knoetzel J (2002) Acclimation of photosynthesis and pigments during and after six months of darkness in Palmaria decipiens (Rhodophyta): a study to simulate Antarctic winter sea ice cover. J Phycol 38(5):904-913

Lüning K (1984) Temperature tolerance and biogeography of seaweeds: The marine algal flora of Helgoland (North Sea) as an example. Helgoländer Meeresuntersuchungen 38:305-317

Lüning K, tom Dieck I (1989). Environmental triggers in algal seasonality. Bot Mar 32:389-397.

Marina TI, Salinas V, Cordone G, Campana G, Moreira E, Deregibus D, Torre L, Sahade R, Tatián M, Barrera-Oro E, De Troch M, Doyle S, Quartino ML, Saravia LA, Momo FR (2018) The food web of Potter Cove (Antarctica): complexity, structure and function. Estuar Coast Shelf Sci 200:141-151

Meredith MP, King JC (2005) Rapid climate change in the ocean west of the Antarctic Peninsula during the second half of the 20th century. Geophys Res Lett 32(19):1-5

Morgan-Kiss RM, Priscu JC, Pocock T, Gudynaite-Savitch L, Huner NPA (2006) Adaptation and acclimation of photosynthetic microorganisms to permanently cold environments. Microbiol Mol Biol Rev 70:222-252

Müller R, Wiencke C, Bischof K, Krock B (2009) Zoospores of three Arctic Laminariales under different $\mathrm{UV}$ radiation and temperature conditions: exceptional spectral absorbance properties and lack of phlorotannin induction. Photochem Photobiol 85:970-977

Nabivailo YV, Titlyanov EA (2006) Competitive relationships in natural and artificial algal communities. Russ J Mar Biol 32:21-31

Nabivailo YV, Skriptsova AV, Titlyanov EA (2014) The interspecific relationships of seaweeds and their role in the formation of communities of Ahnfeltia tobuchiensis (Kanno et Matsubara, 1932) Makienko, 1970 (Rhodophyta). Russ J Mar Biol 40:344-353

Olson AM, Lubchenco J (1990) Competition in seaweeds: Linking plant traits to competitive outcomes. J Phycol 26:1-6

Provasoli L (1968) Media and prospects for the cultivation of marine algae. In: Watanabe A, Hattori A (eds) Cultures and Collections of Algae. Japan Society of Plant Physiology, Hakone, pp 63-75

Quartino ML, Klöser H, Schloss I, Wiencke C (2001) Biomass and associations of benthic marine macroalgae from the inner Potter Cove (King George Island, Antarctica) related to depth and substrate. Polar Biol 24:349-355

Quartino ML, Boraso de Zaixso AL (2008) Summer macroalgal biomass in Potter Cove, South Shetland Islands, Antarctica: its production and flux to the ecosystem. Polar Biol 31:281-294

Quartino ML, Deregibus D, Campana GL, Latorre GEJ, Momo FR (2013) Evidence of macroalgal colonization on newly ice-free areas following glacial retreat in Potter Cove (South Shetland Islands). Antarctica PLoS ONE 8(3):e58223

R Core Team (2018) R: a language and environment for statistical computing. R Foundation for Statistical Computing, Vienna, Austria. Available online at https://www.R-project.org/

Rautenberger R, Huovinen P, Gómez I (2015) Effects of increased seawater temperature on UV tolerance of Antarctic marine macroalgae. Mar Biol 162(5):1087-1097 
Reed DC (1990) The effects of variable settlement and early competition on pattern of kelp recruitment. Ecology 71:776-787

Reichardt W (1987) Burial of Antarctic macro algal debris in bioturbated deep-sea sediments. Deep-Sea Res 34:1761-1770

Schloss IR, Ferreyra GA, Curtosi A, Klöser H, Mercuri G, Pinola E (1997) Factors governing phytoplankton and particulate matter variation in Potter Cove, King George Island (Antarctica). In: Battaglia B, Valencia J, Walton DWH (eds) Antarctic communities: species, structure and survival. Cambridge University Press, Cambridge, pp 135-141

Schloss IR, Ferreyra GA, Curtosi A (1998) Primary production and conditions for phytoplankton growth in Potter Cove, King George Island. In: Wiencke C, Ferreyra GA, Amtz W, Rinaldi C (eds): The Potter Cove Coastal Ecosystem, Antarctica. Rep Polar Res 299:67-73

Schloss IR, Ferreyra GA (2002) Primary production, light and vertical mixing in Potter Cove, a shallow bay in the maritime Antarctic. Polar Biol 25(1):41-48

Schloss IR, Ferreyra GA, Ruiz-Pino D (2002) Phytoplankton biomass in Antarctic shelf zones: a conceptual model based on Potter Cove, King George Island. J Mar Syst 36:129-143

Schloss IR, Abele D, Moreau S, Demers S, Bers AV, González O, Ferreyra GA (2012) Response of phytoplankton dynamics to 19-year (1991-2009) climate trends in Potter Cove (Antarctica). J Mar Syst 92:53-66

Schoenrock KM, Schram JB, Amsler CD, McClintock JB, Angus RA (2015) Climate change impacts on overstory Desmarestia spp. from the western Antarctic Peninsula. Mar Biol 162:377-389

Shea R, Chopin T (2007) Effects of germanium dioxide, an inhibitor of diatom growth, on the microscopic laboratory cultivation stage of the kelp Laminaria saccharina. J Appl Phycol 19(1):27-32

Traiger SB, Konar B (2017). Supply and survival: glacial melt imposes limitations at the kelp microscopic life stage. Bot Mar 60(6):603-617.

Turley C (2013) Ocean acidification. In: Noone KJ, Sumaila UR, Diaz RJ (eds) Managing ocean environments in changing climate: sustainability and economic perspectives. Elsevier, Amsterdam, pp $15-44$

Turner J, Bindschadler R, Convey P, Prisco G, Fahrbach E, Gutt J, Hodgson D, Mayewski P, Summerhayes C (eds) (2009) Antarctic climate change and the environment. Scientific Comittee on Antarctic Research, Cambridge

Turner J, Lu H, White I, King JC, Phillips T, Hosking JS, Bracegirdle TJ, Marshall GJ, Mulvaney R, Deb P (2016) Absence of 21st century warming on Antarctic Peninsula consistent with natural variability. Nature 535:411-415
Weykam G, Wiencke C (1996) Seasonal photosynthetic performance of the endemic Antarctic red alga Palmaria decipiens (Reinsch) Ricker. Polar Biol 16(5):357-361

Weykam G, Gómez I, Wiencke C, Iken K, Klöser H (1996) Photosynthetic characteristics and $\mathrm{C}: \mathrm{N}$ ratios of macroalgae from King George Island (Antarctica). J Exp Mar Biol Ecol 204(1-2):1-22

Weykam G, Thomas DN, Wiencke C (1997) Growth and photosynthesis of the Antarctic red algae Palmaria decipiens (Palmariales) and Iridaea cordata (Gigartinales) during and following extended periods of darkness. Phycologia 36(5):395-405

Wiencke C (1990) Seasonality of brown macroalgae from Antarcticaa long-term culture study under fluctuating Antarctic daylengths. Polar Biol 10(8):589-600

Wiencke C, tom Dieck I (1989) Temperature requirements for growth and temperature tolerance of macroalgae endemic to the Antarctic region. Mar Ecol Prog Ser 54:189-197

Wiencke C, tom Dieck I (1990) Temperature requirements for growth and survival of macroalgae from Antarctica and southern Chile. Mar Ecol Progr Ser 59: 157-170

Wiencke C, Rahmel J, Karsten U, Weykam G, Kirst GO (1993) Photosynthesis of marine macroalgae from Antarctica: light and temperature requirements. Bot Acta 106(1):78-87

Wiencke C, Roleda MY, Gruber A, Clayton MN, Bischof K (2006) Susceptibility of zoospores to UV radiation determines upper depth distribution limit of Arctic kelps: evidence through field experiments. J Ecol 94(2):455-463

Wiencke C, Gómez I, Dunton K (2009) Phenology and seasonal physiological performance of polar seaweeds. Bot Mar 52(6):585-592.

Wiencke C, Amsler CD, Clayton MN (2014) Macroalgae. In: De Broyer C, Koubbi P, Griffiths HJ, Raymond B, Udekem d'Acoz, C d',Van de Putte AP, Danis B, David B, Grant S, Gutt J, Held C, Hosie G. Huettmann F, Post A, Ropert-Coudert Y (eds.) Biogeographic atlas of the Southern Ocean. Scientific Committee on the Antarctic Research. Cambridge, pp 66-73.

Xu D, Li F, Gao Z, Wang D, Zhang X, Ye N, Zhuang Z (2013) Facilitative interactions between the green-tide macroalga Monostroma arctium and the red macroalga Porphyra yezoensis. J Exp Mar Biol Ecol 444:8-15

Zacher K, Savaglia V, Bartsch I (2016) Effects of temperature and interspecific competition on growth and photosynthesis of two endemic Antarctic Desmarestia species. Algol Stud 151(1):103-122

Publisher's Note Springer Nature remains neutral with regard to jurisdictional claims in published maps and institutional affiliations. 